\title{
CHARACTERISTICS OF THE LABOUR MARKET IN THE REGION OF SOUTH BOHEMIA
}

CHARAKTERISTIKA TRHU PRÁCE V JIHOLESKÉM REGIONU

ING. Jaroslav VRChOTA, Ph.D.

ING. MONIKA Bř EZINOVÁ, PH.D.

\author{
Katedra Śzeni $\mid$ Department of Management \\ Ekonomická Fakulta Faculty of Economics \\ Jihol eská univerzita $v$ Leských Bud jovicích University of South Bohemia \\ $\varangle$ Studentská 13, 37005 Leeské Bud jovice, Czech Republic \\ E-mail:vrchotal@ef.jcu.cz,brezina@ef.jcu.cz
}

\begin{abstract}
Annotation
The aim of this paper is to analyze the current state of the labour market in the region of South Bohemia. The main emphasis is the characteristics of the labour market developments in the last 7 years, focusing on the most prevalent forms of discrimination. Data were obtained through personal interviews with employees MPSV, LFS, CSO, Census and data files provided by them. Whithin the post there were characterized the most problematic districts, the proportion of high-risk groups (women, people ZP, over 55 graduates, long-term unemployed) and detailed characteristic of the age and educational attainment. In conclusion of the article, there are defined specific measures leading to increase employment in South Bohemia.
\end{abstract}

\section{Key words}

labour market, discrimination, South Bohemia Region

\section{Anotace}

Cílem $p$ Śsp円 $k u$ je analyzovat soul asný stav trhu práce v regionu jiğních Lech. Hlavní dTraz je kladen na charakteristiku vývoje trhu práce za posledních 7 let se zam గśením na nej! ast †i se

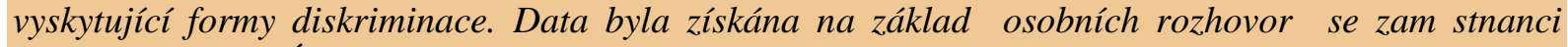
MPSV, VǴPS, LSÚ, SLDB a jimi poskytnutých soubor丁 dat. V rámci $p$ Śisp $\bigvee k u$ byly charakterizovány nejproblematil t'jğ okresy, podíl rizikových skupin (ǵ́ny, osoby ZP, starg் 55, absolventi, dlouhodob门

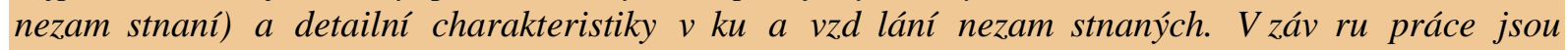
definována specifická opatŚení vedoucí ke zvýgení zam円tnanosti na jihu Lech.

\section{Klị! ová slova}

trh práce, diskriminace, Jihol eský kraj

\section{JEL classification: I21, J64}

\section{Introduction}

In nowadays society there are various differences taken as a part of our lives. However, these differences are directly inicite to some categorization, from which, despite prejudice, stereotyping come to discrimination. There are more types of discrimination, which can sometimes be self-evident, or is slight, hardly traceable and knows about it mostly only affected person. The others seams that everything is fine and does not feel the need for any engange. Today's hectic period is characterized by rigorous competitive struggle and constantly increasing pressure on labour productivity. Therefore, for some groups there are very difficult to take a part in the labour market. 
The labour market in the context of this article is understood as a place where they meet two businesses - businesses and households, through demand and supply of labour. (Holásková, 2008) The labour market differs from the standard product market, its asymmetry, which is caused by the supply side having less choice than the demand side. This is due to the specific nature exchanged a factor of production - labour (labour force), which has not the same characteristics as other goods (Holeman, 2005). The paper focuses on the labour market and is not based on division by Mares (1994) to primary, secondary, formal or informal, external and internal.

Unemployment is an important macroeconomic indicator, which is focused on macroeconomic policy and the general public. Unemployed people are considered those individuals who do not have jobs because of it, either moving to a new job, or at the current real wage can not find work (Nickell 1990). It can differentiate into several types, which fall into three basic categories (Martin, 1990) : The nature, Time perspective, Aspect voluntary .

The very character further by (Bobek, 2007) divided into frictional unemployment (Soukal ová, 2005), often defined as the result of a search for better jobs. Cyclical unemployment (Bobek, 2007), which is referred to as involuntary. This type of unemployment is closely linked to the economic cycle in the economy. It is the result of the overall excess of supply over demand in the overall market. During the recession in the economy it leads to a decline in demand for labour, workers shall be granted and the associated rise in unemployment. A structural unemployment (Samuelson and Nordhaus, 2007), which is the result of a mismatch between supply and demand for labour in various market segments there is structural unemployment. Some sectors and regions develop, thus increasing the demand for labour, while at other places the demand decreases and thus leads to unemployment. In terms of time it can be divided into short-term unemployment, which has mostly seasonal in nature and related to the mismatch of job opportunities during the year. In particular strongly dependent on the weather occurs in industries and occupations, such as agriculture, construction, or surface mining, and associated processing, and manufacturing industries. (German, 2002) Long-term unemployment, which involves not only economic but also social problems. It is not only loss of income and values that could produced the work, but especially the loss of skills, work habits and motivation to work. According to Cleveland (2000), it is more than 6 months.

The last aspect is the division between voluntary and involuntary. Voluntary unemployment, according to Krebs (2007) appears in two cases, and if a person wants to work, but looking for higher wage assessment than the one that prevails in the labour market or in the second case, on the contrary, a person does not want to work and does not look for vacancies . In the first case, it is primarily an individual who has a sufficient amount of money saved up, prefers leisure and can " afford" not to work. In the latter case, this is particularly relevant for those who have learned to use social system and chooses rather modest life without work. Voluntary unemployment, there is plenty of vacancies in the labour market, but there is no interest in them. In contrast, involuntary unemployment may become a serious problem for the economy. Arises when the labour market has not enough vacancies and the high demand for them. Unemployed trying to find a job with a salary that is in the labour market, normal or even lower, although vacancy can not be found. According to Holman (2005) it may be the cause of involuntary unemployment, state intervention in the labour market, such as setting minimum wages or trade union activity - namely preventing the decline in wages and prevent people who would be willing to work for low wages, to get job (Human 1987, Dobre 2007).

The labour market has a significant impact by (Swift, 2005) perception and attitude toward risk groups, which, in the professional literature (Browne, 2009; Goldscheider, 1992; Kane, 1998) can be divided into : age limits, restrictions in terms of gender, qualification for basis of disability negative in pack dominate in most cases. These impacts can be divided according to Giddens (1999) in to economic and social issues. After you can accommodate a number of aspects. With the loss of jobs there is always associated a change of social status, standard of living and social role unemployed. There is also the risk of social isolation or social failure, all consequences of unemployment affects not only the unemployed but also the surrounding area - primarily family. There are for many 
economists, hardly understandable reasons, the long-term aim of reducing unemployment in the regions.

\section{Methodics}

The aim of this paper is to analyze the current state of the labour market in the region of South Bohemia. The main emphasis is the characteristics of labour market developments in the last 7 years focusing on the most prevalent forms of discrimination.

In the Czech Republic there are currently three ways to find out information about the labour market. Information can be obtained from the labour offices published the Employment Services Administration of the Ministry of Labour and Social Affairs of the Czech Republic ( portal MPSV), data based on the Labour Force Survey (LFS ) issued by the Czech Statistical Office data based on a census of houses and flats (Census). Mostly the necessary data were obtained from these sources. The work was also drawn from published Eurostat data, needed especially for the European Union. Information concerning the main areas of unemployment in both the individual 's and the selected region. Data on discrimination are based largely on the structure of the unemployed in terms of age and education, where the selection of these two groups is based on (Arrow, 1998). The structure of unemployed by education follows the structure of vacancies, which is divided by just learning. Custom Data were collected through in-person consultation with employees MPSV, the Census and UP. A subsequent processing of the acquired data and summaries. Data processing was carried out in MS Excel, as well as subsequent outputs.

\section{Results}

Before entering the Czech Republic to the EU, the situation on the labour market in the Czech Republic and in South County worsened since 2000. At the beginning of 2004, the unemployment rate exceeded $11 \%$ in the Czech Republic. Since then, the unemployment rate has been over $10 \%$. Compared to previous years, 2006 saw an annual decrease in the unemployment rate in South Bohemia, by $1 \%$. The reduction takes place in the same year in all the districts. All the districts of the region have at the end of 2006, a lower unemployment rate than the national average, except the district of Czech Krumlov. The South Bohemian region, we can say that is one of the areas in the Czech Republic with below-average long-term unemployment. Chart 1 shows that in 2007 and 2008, the unemployment rate was well below 5\%. The lower unemployment rate than in the South Bohemian region had in 2007 only 3 of the 14 regions, and the city of Prague, Central Bohemia Pilsen Region and in 2008 it was only the city of Prague. Since 2009, the unemployment rate has begun to increase, but the value does not exceed eight percent. In this period it was the worst district of Czech Krumlov, which is kept below $10 \%$, then on the contrary the Czech Bud円ovice district does not exceed $6,5 \%$. 
Fig. 1: The average unemployment rate in JK ( in\%)

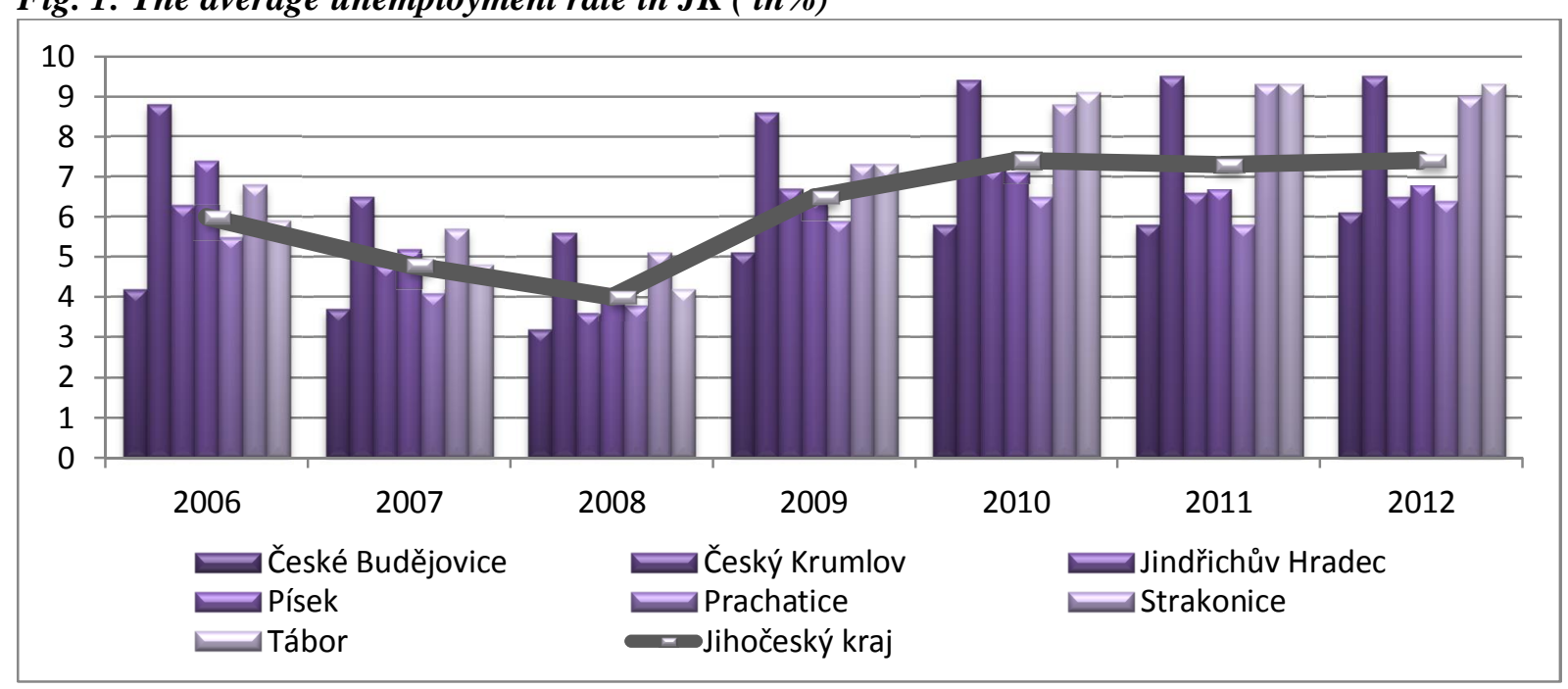

Source: Portal MPSV, the actual processing

To 31.12th 2012 there were in South County total 28,767 job seekers, which is compared to the previous year, an increase of 2,317 people over the past seven years, however, this indicator increased by about 8,341 people - see Figure 2 In the reporting period, the number of candidates in the 2008 first declined, then grew an average of 10 to 12,000 in 2010, which reached its peak of 29,545 applicants, since the number slightly decreased. The average number of unemployed in the region is for the year 23,811 applicants.

The number of unemployed women increased between 2006 - 2012 the number of 11408 to 14126 (24\%). The trend was similar with the number of job seekers in total. The highest increase in the number of unemployed women was recorded in 2009, when the number increased by almost four and half percent. The last two years, the evolution of female unemployment rather grew character.

Different development was the number of job seekers with altered working ability. The share of peple with disabilities in 2006 was $16.4 \%$ of the total number of applicants in the South Bohemian Region. The following year, this share increased to $19.6 \%$, but since 2008 the number of applicants still declined. Last year, the share to 31.12 th $13.0 \%$ in 2012. In the reporting period, this structure candidates in South County decreased by $3.4 \%$, to 3,758 applicants.

The proportion of school leavers and young people from 2006 to 2012 ranged from 7.0 to $8.2 \%$. The highest proportion was reached in 2008, when their number was 1,427 applicants. Conversely, the lowest number was recorded in 2012, when their share in the total number of applicants was $7 \%$. We can finde the same results in Winklerové and Ġvecová.

In contrast, the number of applicants over 55 years has increased. To 31 12th 2006 the group of applicants was $12.6 \%$ (2,580 people), in the following year it was already $15.1 \%$. Between 2008 and 2009, the number declined, but in 2010 the number of applicants has again started to rise last year, the proportion of $15.4 \%$, which corresponds to 4,437 applicants.

Long-term unemployed accounted for the group of applicants in the period, which had the highest share in the total number of job seekers in South County. Number of long-term unemployed has increased in the years 2006 - 2012 the number 940913820 In 2009, he recorded the highest increase in the number of long term unemployed by nearly $8 \%$. In the last three years there is an increase in this indicator, compared to 2010 , this increase amounted to 1,683 applicants. Increase in long-term unemployment has led to a gradual increase in their share of the total number of job- seekers from 32 $\%$ in 2008 to $48 \%$ in 2012. 
Fig. 2: Structure of the candidates in the districts of South Bohemia (in thousands)

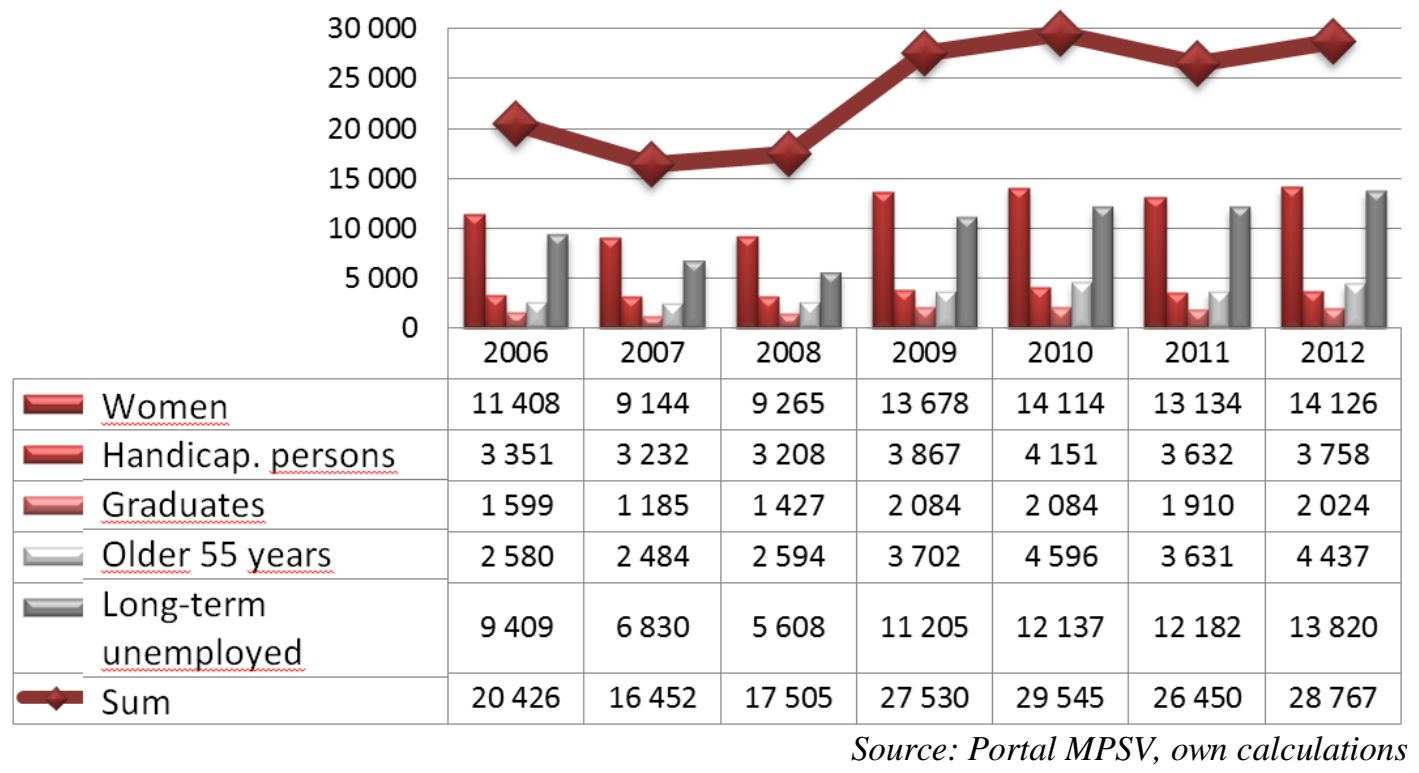

The number of vacancies in the last seven years has changed enormously, both across the region and in individual regions. In 2006, the number of vacancies in 5222 over the region, at the end of 2012 it was about 1,359 more jobs. In contrast, with regard to the number of job seekers, this increase was not particularly high. It is evident from this that the number of applicants per job in 2012 amounted to 4.4 people. As table 1 shows, the least of vacancies was in 2009 - 2012. Most vacancies were recorded in 2007. The region is the best in the Czech BudDovice region, the imaginary second place in Strakonice region. Conversely Prachatice region was the worst. Last year in this region there were registered only 597 vacancies, it meens that one job had 3.6 candidates. For comparison, at the end of 2007, before the economic crisis it was only 1.7 job seekers. The last two years show that the number of vacancies, both in individual districts and throughout the region increased.

Tab. 1: Number of job vacancies in South County

\begin{tabular}{|l|c|c|c|c|c|c|c|}
\hline & 2006 & 2007 & 2008 & 2009 & 2010 & 2011 & 2012 \\
\hline L̦eské Bud円ovice & 1498 & 1597 & 1290 & 550 & 652 & 853 & 1740 \\
\hline L̦eský Krumlov & 441 & 704 & 383 & 114 & 129 & 215 & 713 \\
\hline JindŚchTv Hradec & 448 & 644 & 387 & 116 & 159 & 170 & 1010 \\
\hline Písek & 837 & 1119 & 421 & 159 & 176 & 138 & 830 \\
\hline Prachatice & 406 & 738 & 317 & 155 & 194 & 164 & 597 \\
\hline Strakonice & 803 & 1219 & 1038 & 306 & 372 & 330 & 765 \\
\hline Tábor & 789 & 962 & 384 & 116 & 168 & 203 & 926 \\
\hline Jihol eský kraj & 5222 & 6983 & 4188 & 1516 & 1850 & 2073 & 6581 \\
\hline
\end{tabular}

The number of job seekers is closely related to their age, as shown in Chart 3 Previously, they were the worst positionable group of applicants under 19 years, in recent years it has, but there are people in the group from 20 to 34 years. To 31.12th 2006 the region recorded 7,595 candidates aged 20 to 34 years. In the past year the number of applicants increased to 10170 The lowest value for the last seven years was reached in 2007, when the number mentioned in the group amounted to 5,626 applicants. The lowest numbers in the reporting period amounted group under 19 years. The number of people over 50 also more increases, where the difference between the years 2011 and 2012 amounted to 3,831 applicants. 
Fig. 3: Structure of job seekers by age in JK

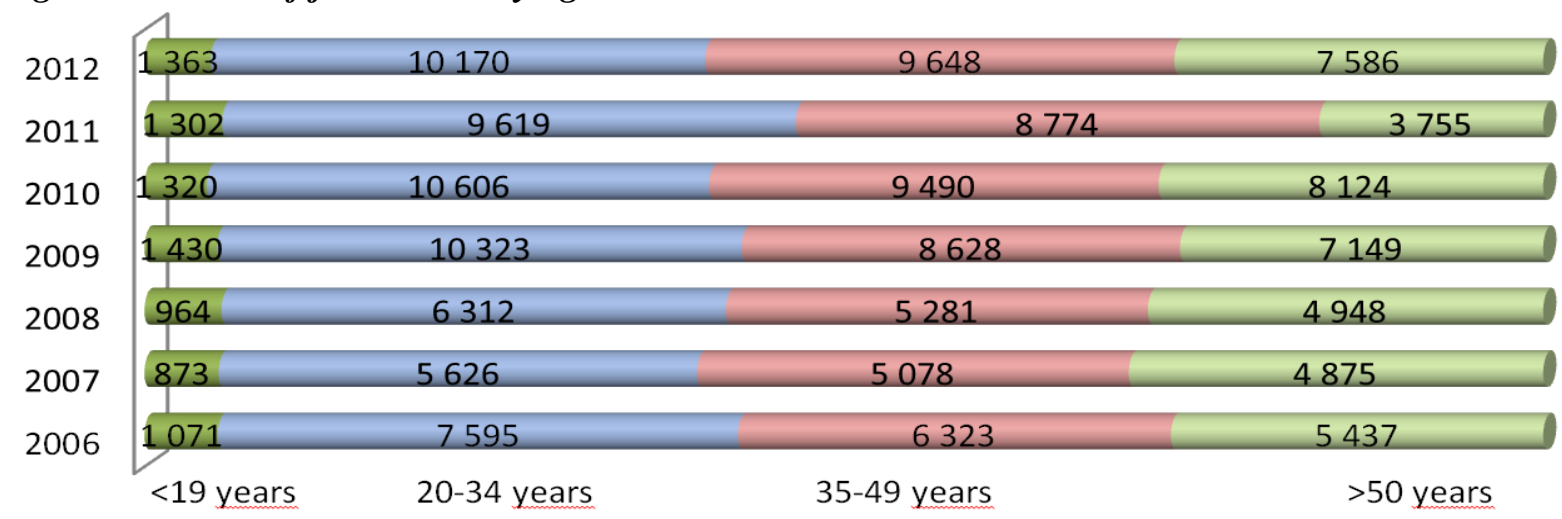

Source: Portal MPSV, the actual processing

The structure of job seekers by educational attainment reflects the requirements of the labour market training the workforce on one hand and on the other hand, the educational structure of economically active people in the various territorial units. The highest number of job seekers is permanently in a group of vocational school graduates with no school-leaving certificate when their number increased for 7 years from 9013 to 13,181 , ie by 4168 , as shown in Table 2 . The most significant increase was in vocational education between 2008 and 2009. As the second highest group we can identify candidates with primary or no education. In comparison, as at the end of 2012, thare was recorded by 628 more of these candidates than in 2011. The proportion of these candidates ranges in the period ranging from 23 to $27 \%$. The third highest group consists of high school graduation. Their number in the reporting period increased by 1,683 candidates. The lowest number of these candidates was recorded in 2007, when their number was 3902 last year there were 6,434 registered candidates. The lowest values in the reporting period amounted to graduates of colleges and universities. The difference between 2006 and 2012 amounted to 934 applicants.

Development of the number of candidates by individual educational categories in South County is virtually unchanged. Throughout the seven years apprentices or candidates with secondary education without GCE prevail.

\section{Tab. 2: Structure of the job seekers' education in JK}

\begin{tabular}{|l|c|c|c|c|}
\hline \multicolumn{5}{|l|}{ Structure of the job seekers' by education } \\
\hline & $\begin{array}{c}\text { Basic education and } \\
\text { without education }\end{array}$ & $\begin{array}{c}\text { Secondary without } \\
\text { GCE }\end{array}$ & Secondary with GCE & University \\
\hline 2006 & 5716 & 9013 & 4751 & 946 \\
\hline 2007 & 4516 & 7167 & 3902 & 867 \\
\hline 2008 & 4594 & 7681 & 4201 & 1029 \\
\hline 2009 & 6601 & 12623 & 6778 & 1528 \\
\hline 2010 & 7024 & 13920 & 6860 & 1741 \\
\hline 2011 & 6644 & 11935 & 6125 & 1746 \\
\hline 2012 & 7272 & 13181 & 6434 & 1880 \\
\hline
\end{tabular}

Source: Portal MPSV, the actual processing

\section{Conclusion}

Unemployment rate in the South Region in the years 2006 to 2012 corresponds to the unemployment rate in the Czech Republic. No hige difference, but still ranks among the counties with the lowest unemployment. It is a region that is not too linked with manufacturing and mining and quarrying, and so you will find many jobs in other sectors. This is mainly in agriculture, logging and livestock production and it is by-production. Neither Region is except for the occurrence of discrimination in 
the labour market. Among the groups that have worsened conditions for their application at the labour market are: a group of job seekers among 20-34 year women before and after maternity leave and job applicants over 55 years.

In the long term the worst in the issue of unemployment in the Region is the township of Czech Krumlov, which exhibits during the whole period the unemployment rate around $10 \%$. Less unemployment and long-term balance show: District and Sand. The best is in the last seven years, Czech Bud円ovice district, the unemployment rate does not exceed six and half percent. The number of job seekers in the districts of South Bohemia Region from 2006 to 2012 steadily increased. The difference between 2006 and 2012 in the group of long-term unemployed amounted to 4,411 applicants. Number of job seekers over 55 years was in 2012 - 1857, which was more than 806 applicants in 2011. Group of graduates and youths faced with the highest unemployment in 2009 and 2010. From this period their number in 2012 fell slightly. Development of applicants with reduced work capacity in the years 2006-2012 volatile. At the beginning of the period, their number declined, the increase occurred in 2009 and 2010, after more years, they were re- reduction. In the reporting period, the highest unemployment rate recorded in women. Their number in any year does not drop below nine thousand. Last year, the value of job seekers was 14126.

In a survey job vacancies were recorded during the period under high differences. In 2006, the number of job vacancies 5222 in 2009 it was only 1,516 and in 2012 the number increased to 6,581 vacancies. From this it means that last year accounted for 4.4 per job applicants. In the structure of unemployed divided by age the most powerful group of people from 20-34 years old became, followed by the age group 35-49 years. In 2012, the value of the mentioned candidates amounted to over 9500 A group of applicants over 50 years, the number of its ranks the third in the structure of unemployment was broken down by age.

Most of the unemployed divided by a group is vocational education and secondary education without GCE. Their highest value was recorded in 2010, 13920 In contrast to the most leading universityeducated people. The lowest value of this group was 867 applicants in 2007 . The article is a part of project GAJU ! . 039/2013-S and GAJU ! . 079/2013-S.

\section{References}

[1] ARROW, J., Kenneth., (1998) Chat Has Econoics to Say about Racial Discrimination? The Journal of Economic Perspectives, vol. 12, iss. 2 pp. 91-100. ISSN 0895-3309. DOI 10.1257/jep.12.2.91.

[2] BOBEK, M., BOUL, KOVÁ, P., KÜHN, Z., (2007). Rovnost a diskriminace, 1. vydání. Praha: C.H.Beck,. ISBN 978-80-7179-584-1.

[3] BROWNE, A., (2009). The Retreat of Reason. Politoval correctness and the corruption of public debate in modern Britain. Vyd. 1. Praha: DokoŚn. ISBN 978-80-7363-240-3.

[4] CLEVELAND, J., STOCKDALE, M., MURPHY, R., K., (2000). Women and men in organizations: sex and gender issues at work. New Persey: Lawrence Erlbaum Associates. ISBN 0-8058-1268-7.

[5] DOBRE, M., DUDIAN, M., TRASCA, D., (2007). Discrimination on Labour Market. In International Economic Conference Location. Sibiu: Lucian Blaga University. pp. 149-153. ISBN 978-973-739-428-6.

[6] GIDDENS, A., (1999). Sociologie. Praha: Argo. ISBN 80-7203-124-4.

[7] GOLDSCHEIDER, F. K., GOLDSCHEIDER, C., (1992). Gender Roles, Marriage, and Residential Independence. Sociological Forum, vol. 7, iss. 4, pp. 679-696. ISSN 1573-7861. DOI 10.1007/BF01112321.

[8] HOLÁSKOVÁ, R., (2008). Politika zam П̧.tnanosti. Ostava: Ostravská univerzita v Ostravク ISBN 978-807368-522-5.

[9] HOLMAN, R., (2005). Ekonomie. Vyd. 4. Praha: C. H. Beck. ISBN 80-7179-891-6.

[10] HUMAN, L., (1987). Labour Ï market discrimination in manufacturing sector ï the impact of race, gender, education and age on income. South African Journal of Economics, vol. 55, iss. 2, pp. 150-164. ISSN 1813-6982. DOI 10.1111/j.1813-6982.1987.tb01096.x.

[11] KANE, E. W., (1998). Men's and Women's Beliefs about Gender Inequality: Family Ties, Dependence, and Agreement. Sociological Forum, Plenum Publishing Corporation, vol. 13, iss. 4, pp. 611-637. ISSN 15737861. DOI 10.1023/A:1022895317075.

[12] KREBS, V., a kol., (2007). Sociální politika. Vyd. 4. Praha: ASPI, s.s. ISBN 978-80-7357-276-1. 
[13] MAREG P., (1994). Nezam Пthanost jako sociální problém. Vyd. 1. Praha: Slon ï sociologické nakladatelství. ISBN 80-901-4249-4.

[14] MARTIN, J., (1990). Deconstructing Organizational Taboos: The Suppression of Gender Conflict in Organizations. Informs.

[15] N'nMEC, O., (2002). Lidské zdroje na trhu práce. Praha: Vysoká ġkola ekonomická. ISBN 80-245-0350-6.

[16] NICKELL, S., (1990). Unemplyment: A Survey. The Economic Journal, vol. 100, iss. 401, pp. 391 ï 439. ISSN 1468-0297. DOI 10.2307/2234131.

[17] SAMUELSON, P. A., NORDHAUS, W. D., (2007). Ekonomie. Praha: NS Svoboda. ISBN 8020505903.

[18] SOKAL OVÁ, L., (2006). Kariéra, rodina, rovné pŚleğitosti: výzkumy postavení ǵ́n a muğđ na trhu práce. Praha: Gender Studies. ISBN 80-86520-12-9.

[19] SWIFT, A., (2005). Politoval Philosophy. ABegginners' Guide for Students and Politicians. Praha: Portál. ISBN 80-7178-859-7.

[20] ĠVCOVÁ, A., RAJḶAKOVÁ, E., (2012). Development of unemployment among school leavers. In 15th International Colloquium on Regional Sciences. Conference Proceedings. Brno: Masarykova univerzita. pp. 475-485. ISBN 978-80-210-5875-0.

[21] WINKLEROVÁ, L., (2012). Unemployment of graduates of economically oriented faculties in the South Moravian Region. In 15th International Colloquium on Regional Sciences. Conference Proceedings. Brno: Masarykova univerzita. pp. 466-476. ISBN 978-80-210-5875-0. 